\title{
Driving Forces of Wage Gap and its impact on Female Participation on Economic Growth: Evidence from in Egypt, Malaysia and Pakistan
}

\author{
Doaa Salman Abdou*, Heidy Nasser, Naglaa Nasr and Dina Shalaby \\ Department of Economics, October University for Modern Sciences and Arts (MSA), Egypt
}

Submission: November 28, 2018; Published: February 14, 2019

${ }^{*}$ Corresponding author: Doaa Salman Abdou, Department of Economics, October University for Modern Sciences and Arts (MSA), Egypt

\begin{abstract}
This research paper tackles the determinants of wage differentials and wage inequality in Egypt and Malaysia, as well as their impacts on the economy. However, women tend to be so discriminated up until now, despite the enormous development we have been through, they still get paid less than men. Therefore, this paper aims to know the role of women and how they influence economic growth. Moreover, the study is carried upon the period 1990-2017. The paper concludes that education and human capital have a great role in determining wages and acquiring women an opportunity of getting higher earnings. Closing the wage gap is somehow hard for Egypt as it is a low-income country. While, Malaysia showed a downward trend in the female participation rate in the labor market in 2006 than in 1992 for different cultural perspectives and obstacles facing women in the Malaysian labor market. Furthermore, women turned to have a positive impact on economic growth according to the Feminization U' Model. Also, we used Belgium and Pakistan as a case study to reflect how they overcame gender discrimination in wage pay due to different policies they implemented and trade unions they joined.
\end{abstract}

JEL Classification: J7, J4, J31, B54

Keywords: Gender Discrimination; Wage Differentials; Labor Market; Feminism

\section{Introduction}

Wage inequality has always been a topic that is interesting for debating and has grabbed most of economists and people's attention. The wage gap between males and females is a significant issue as it affects the lives of almost everyone. This implies, that it also has a great impact on females, their children and the next generation as well. Thus, the determinants of this wage gap should be figured out so that we can implement policies that eliminate this income disparities.

In recent years, the wage inequality has been studied in most of the developing and developed countries, including Egypt and Malaysia, the countries we are carrying on our study in this research paper. This difference was associated with the existence of gender discrimination against women in labor market. Moreover, this discrimination was highlighted to have a major consequence economically, politically and socially- calling for some corrective actions.

This research paper focuses on studying the determinants of the wage gap found in Egypt and Malaysia. Researches were made to shed light on the main cause of this difference and so we can implement policies that overcome the problem as there is a research gap regarding this topic that we are trying to fill and recommend a solution for the problem. Moreover, we are going to explore the impact of the increase in female participation in the labor market on economic growth using the Feminization $U^{\prime}$ Model and the three stages the economy passes through.

The plan of this paper goes as follows: in the literature review section we will identify the determinants of wage gap in both countries, Egypt and Malaysia. Then, the following section we will analyze and make a comparative study based on the different factors we get for each country, supported with numerical and real data obtained from the world bank, etc. Afterwards, we will provide a case study on Pakistan to show what policies and regulations they use in order to overcome discrimination and do better than Egypt and Malaysia. Later, we will discuss the positive impact of female participation in the labor market. Finally, we will reach a conclusion that shows mostly discrimination against women is the main reason behind the wage gap in both countries. We can also conclude that, women participation will boost economic growth as it increases labor supply and lowers the wage rates, as well as contributes to higher income for households. 


\section{Literature Review}

Adam Smith (1776) was the first to introduce the equalization/ compensating wage differentials model to explain the equilibrium in the demand and supply of the labor. According to Smith (1776), the whole pros and cons of the job was what is equated across jobs in a competitive market and not the wages. He introduced five main factors of wages, including:

a) the willingness or unwillingness of the employees themselves.

b) how easy and cheap it is to learn the tasks, or how hard and expensive it is.

c) the constancy and inconstancy of employment in them.

d) how much they trust those who train them.

e) the probability of their success.

While, Becker model highlights that the higher the competition for final goods in the market, the lower the discrimination should be against the groups of minorities in the labor market. This clear conclusion results from the existence of economic rents required by the labor market's discrimination. When there are economic rents paid, the employers prefer to pay the employees a smaller value, below their marginal productivity's level [1].

Also, Becker (1957) argues that differential's percentage is not always related to resource allocation. However, it is more relevant when attempting to explain the differences in the relative demand for skilled and unskilled workers. Likewise, it is also significant when it comes to determining the variations in resources devoted to human capital, such as education and training as devoted to other uses. This is because every dollar returned on human capital invested is represented by the skills differentials.

Economics always explore the recognized gender segregation in the labor market over some different conditions and around two important axes. However, to be more specific, the economists target the determinants of the women participation in labor market and the side of supply, while, the investigations examine the different treatment of females in the labor market which is regularly mirrored in somehow much less incomes and unequal chances in occupations for some women Domingo (1989). Human capital theory is based on the decisions made by female and male students, workers and employers and on the hypothesis that everyone has accumulated a stock of human capital according to his investment in education and formation. The theory of human capital in 1962 [2] mainly showed the gender discrimination in firms' wages. Generally, the differences on wages must be only based on differences in knowledge, abilities or skills owned by the worker or employee. Another difference on wages can happen due to professional and educational differences between the workers since the professional or educational experiences help increase productivity and the performance of employees.

It is believed that the difference in socialization between men and women even before entering the labor market creates differences in skills and abilities between males and female workers since women don't spend in human capital as much as men do. So, according to the theory, women aren't discriminated against in the labor market or rewarded less due to segregation causes but because the women own less human capital and less productivity then men in the labor market as well (Becker, Investment in Human Capital: A Theoretical Analysis, 1962) [2].

This section reviews the main factors that contribute to the wage gap between men and women. The gender wage gap is the difference of the women's wage as a percentage of the men's wages. According to Polachek [3], he highlighted that it is also a statistic summary of a person's education, training and expected future participation. We could think that discussing such an issue is insignificant in the $21^{\text {st }}$ century. However, it is sad that we face a huge inequality problems and women still get paid less than men up until now, despite the major developments and flourishment we have been through.

Hence, what are the main factors that contribute to such disparities? In 2011, the United States Accountability Office report found out that women are highly productive and more educated than ever before, but their pay hasn't yet caught up with them. More than race, social-economic status or education, the gender is still the main reason behind this wage gap. They also found that women get affected by this gap at all their income levels and occupations and widens as they grow older.

Taking care of the children is another factor that majorly afflicts women from having a good paying job wage. Statistically, women are more likely to be childcare providers than men, that is something that has been known throughout the time and that the society established. Saul (2003) also asserted that high paid and most secured jobs have requirements that contradict with a childcare provider and are difficult to be met. Moreover, the traditional female image influences the women's perception of their abilities and make them underestimate their potential. Therefore, the selection procedure for those who can meet the difficult job requirements will result that far more men find suitable jobs with benefits and good pay than women Paul (2003).

Likewise, another factor for the disparity in wage gap is the gender segregation in work sector. Women tend to work in administrative positions, public sector, retail, part-time and flexible work. They join such jobs in order to balance between their work and responsibilities, which are mainly their home and children. On the other hand, men are most likely to be found in jobs such as construction and manufacturing which pay more compared to female-dominated jobs with comparable skill levels. Thus, females predominate in lower paid jobs such as nursing and teaching. While, males predominate in jobs such as architecture and computer occupations. GAO mentioned that women must tolerate subtle bases to acts of gender discrimination relating to pay raises, pregnancy and others of women's responsibilities [4].

According to Ali (2015), Glass Ceiling problem is one of the numerous problems raised due to forcing gender inequality in 
the workplace and the idea of who is the foremost influencer of the work. This issue could be also defined as the Glass Pyramid which shows the hierarchy of employees, and gender pay gap that could be realized easily through the diversification of wages paid [5]. In other words, the Glass Ceiling can be defined as an invisible barrier that keeps women, minorities, and people of color from rising to the upper rungs of the corporate ladder. Regardless of their qualifications or achievements they cannot break through the glass ceiling to the upper level of management. According to the UN, 2013, gender equality is necessary whether in workplace or any other sector, for having a peaceful life and a sustainable world. Gender equality does not mean that women and men are the same. Instead it could be defined as that the rights, opportunities and responsibilities have nothing to do with the gender. It does not depend on whether this person in a male or a female.

Feminization of the workplace links to the Marxist approach where everyone has the gift to vend their labor power, to gain the means of production. It is not a secret that generally women are paid less than men in almost all professions all over the world. The Marxist theory mainly focused of the impact of the capitalist system on labor force segregation. This theory argued that women are considered reserve army of labor; this means that women could only be employed in case there is scarceness in the labor market. According to Ali, 2015, the Marxist theorists demonstrated that the reason for labor inequality is because of the disagreement between labor and capital [6].

They were harshly criticized by radical feminists and by many scholars because of neglecting both the role of women in the society and the role of childcare by women. The Marxist theorists' point of view seemed to be unrealistic that's why they were always severely criticized. Another classical theory is the Radical feminist theory that started by believing that the main reason behind the gender inequality is belief that men have more power than women. Generally Radical feminists had a dissimilar point of view than the Marxists theorists and that was a cause for the disapproval Ali (2015). Until a dual system theory raise, that realized that neither the Marxist theorists nor the Radical feminists could work solely. The action of fusion of both theories led to the rise of a totally new one named the Socialist Feminist Theory of Capitalist Patriarchy. This theory was considered mainly a criticism for Marxist and Radical school by regarding the role of women in labor force.

According to Simmonds (2012) the Feminism Theory criticized many other theories that stated that women's role is only concentrated on the child care and the housework. Feminism theory stated that both things do not influence the women's ability to work. In addition to many other important theories such as the Neo-classical Theory that stated that workers are rational, and firms target minimizing cost as much as possible and maximizing profit in return. Moreover, they argued that women have more responsibilities than men which make them less skilled, and less experienced and that's unattractive to firms.
Gender pay gap is a response due to the gender discrimination, and it means that men and women are not paid equally; there is a huge gap between their wages. Commission (2013) this gap will lead to a complete destroy in the economy because women will start thinking that there is no incentive to be educated from the beginning if they will not be paid well at the end. When women start thinking that it is useless to go to schools and as a result a whole new generation will be uneducated. When a lot of people become uneducated, poverty will extend extremely and eventually the whole economy will be destroyed.

\section{Wage differentials in Egypt}

Based on our studying country, Egypt, Said \& Mona (2006) indicated that women's reward significantly improved by 2006 than in 1998. Governments started paying them more than any elsewhere and the wage gap declined than in the past. However, El Haddad \& Amirah (2008) showed that the main reason of women getting lower wages than men was mainly a result of discrimination based on sex. They then carried another study in 2011 and conducted that men have an hourly wage which is $29 \%$ higher than women as they are found in lower-paid occupations and firms (CAPMAS,2015).

In addition, it was observed that large number of females quit the labor force after marriage, decreasing their participation rate. Also, Herrera \& Badr (2011) mentioned that returns to education and experience in Egypt increase proportionally with the increase in firm size and are larger in formal sectors. However, the female participation rate tends to be higher in informal sectors than formal sectors, that is mainly why they get paid lower wage than men. It is well-known that government has been equal in its treatment of male and female job seekers workers, while the private sector strongly discriminates against women in both hiring and compensation [7].

Whether this gender discrimination is economically justifiable or not, it results in highly encouraging women to go for government employment rather than private businesses [8]. Such strong preferences are also derived from the differences found in private and public sectors related to their working conditions offered to the job seekers. For instance, working hours, access to paid vacation, sick and maternity leave, exposure to the risk of sexual harassment. Many, if not most, private sector jobs in Egypt do not meet women's minimum acceptable threshold in terms of working conditions, a phenomenon that has been referred to as "reservation working conditions" [9].

These Unacceptable jobs could involve work alongside male co-workers or bosses in a small workplace lacking other women, work outside in exposed situations, potentially risky interactions with customers of the opposite sex, long commutes to work that expose women to the risk of harassment or attack, a need to reside away from home for periods of time, or simply work in occupations deemed not suitable for women [7]. The need to ensure acceptable working conditions limits women's employment to a narrow 
number of labor market segments in the private sector, leading to over-crowding of women in these segments and downward pressure on wages, making even the socially acceptable jobs less desirable.

\section{Wage differentials in Malaysia}

In Malaysia, few studies have been carried out to identify the factors of wage differentials and most of them concentrated on the role of training and education. Chua (1984) used the Household Income Survey in 1973 and Labor Force Survey of 1974 to examine the wage disparities by sex. Moreover, he concluded that about $36-74 \%$ are unexplained variables that contribute to wage differentials (African Journal of Business Management,2015). While, Chapman and Harding (1985) highlighted that most of the differences found in the wages of men and women are mainly because of the differences in occupational distribution, where women are found in lower-paid jobs. In addition to this, it was estimated that women earn about $71 \%$ of men's wages (African Journal of Management,2015) [10].

Latifah (1988) then came and used the data from the Malaysian Family Survey 2 (MFLS2) in 1988 and found that most of the earnings disparities in Malaysia attributed to unexplained variables. While, the explained variables contribute to a very small degree. This proves that the discrimination effect in the Malaysian labor market is quite serious. On the other hand, Rahmah and Zulridah (2005) found that explained variables have major contribution to wage differentials while the unexplained variables attribute to a very low percentage. The most important factors include, human capital, job characteristics and demographic factors. The neoclassical theory then focused on productivity and wages by gender [11].

The workers are paid according to their productivity as the employers seek to maximize profit. Even though men and women are equally educated, women are said to be lower productive than men and therefore, get lower pay. This is referred to as employer's discrimination [12]. There are many studies that have been made to measure the women's fertility rate and examines its effect on female labor's participation. For instance, Ismail \& Sulaiman [4] studies showed that the women's labor supply was highly influenced by the number of children they have according to the field survey in Malaysia and the data collected in 2011. Also, Mason and Palan (1981) asserted that there is an inverse relationship between the female labor force participation's rate and the fertility rate, supported by the analysis of the 1974 Malaysian [13].

Women in Labor Market \& The Wage Gap: Egypt, Malaysia And Pakistan

\section{Egypt FLFP and Economic Growth in economic growth}

In Egypt, women in the labor market are strongly discriminated against with only $25 \%$ of them participating in the labor force compared to men who represent $79 \%$ of the labor force (Economic Research Forum, 2017) [14]. Although, the government doesn't make a clear policy protecting women against discrimination, but the NGO's and donors are in field of women's empowerment. Similarly, Egypt ranks the 134th country, recording a decline in wage equality for similar work, data show increase in gender parity in tertiary enrolment (Figure 1).

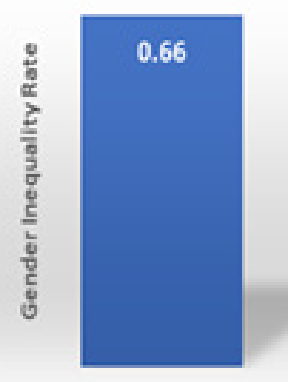

2000

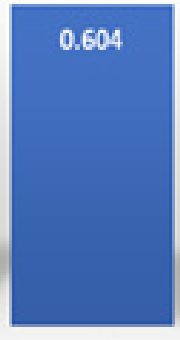

2005

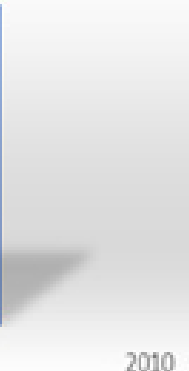

2010

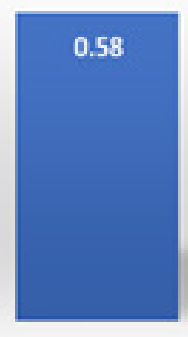

2013

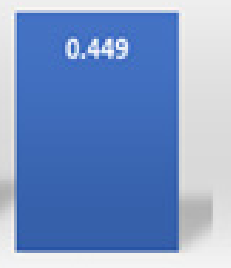

2017

Figure 1: Gender Inequality in 2000-2017, Egypt. Source: United Nations Development Programme, Human Development Reports, 2018.

Furthermore, Egypt is a country with low income closed only $67 \%$ of the labor market participation wage gap (Economic Research Forum, 2017). Thus, we can see through the above (Figure 1) that the gender inequality's rate is decreasing throughout the years in Egypt. This is because of the 2014's constitution which provided several articles protecting women (Figure 2). Note: $31,149,152$ people are participating in the Egyptian labor force World Bank (2017).
However, the female participation rate in the labor force tends to be so much lower than the male's participation in the labor force, where the minimum participation rate for men was 71.17 $\%$ in 1998 and reached the maximum of $75.88 \%$ in 2012 (World Bank, 2017). While, the female's participation rate hits a minimum of $18.83 \%$ in 1998 and a maximum of $22.86 \%$ in 2009 (World Bank, 2017). There is a quite major gap between both rates. This means that the Egyptian women did not even reach one forth the number of working men in the labor market (Figure 3). 


\section{Annals of Social Sciences \& Management studies}

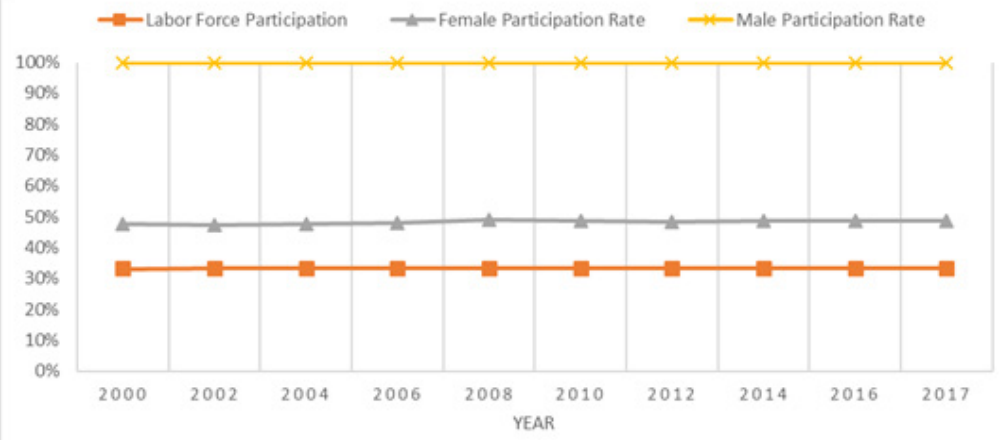

Figure 2: Female Participation Rate in the Egyptian Labor Force 2000-2017. Source: World Bank, 2017.

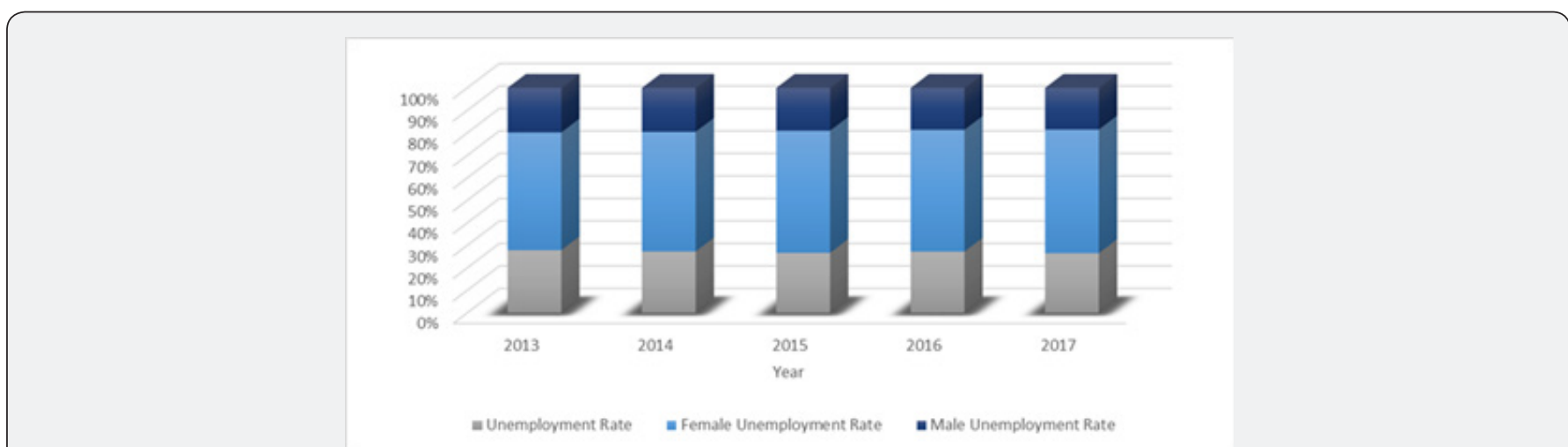

Figure 3: The Unemployment Classification Rates in Egypt, 2013-2017. Source: World Bank, 2017.

Here in the diagram, we can see that the minimum unemployment rate for men reaches $4.67 \%$ in 2009 and a maximum of $9.53 \%$ in 2013. On the other hand, the average unemployment rate for females was $23.27 \%$, reaching a minimum rate of $19.16 \%$ in 1999 and a maximum of $26.66 \%$ in 2003 (World Bank, 2017) which is more than double of that of men. Thus, the women in Egypt face unemployment problems almost 3 times the men. Also, the decrease in men's unemployment rate is double the decrease from that in the women (Table 1).

Table 1: Global Gender Gap Score, Egypt 2017. Source: World Economic Forum, 2017.

\begin{tabular}{|c|c|c|c|c|}
\hline \multirow{2}{*}{ Global Gender Gap Score } & \multicolumn{2}{|c|}{2006} & \multicolumn{2}{c|}{2017} \\
\cline { 2 - 5 } & Rank & Score & Rank & Score \\
\cline { 2 - 5 } & 109 & 0.579 & 134 & 0.608 \\
\hline $\begin{array}{c}\text { Economic participation } \\
\text { and opportunity }\end{array}$ & 108 & 0.416 & 135 & 0.413 \\
\hline Educational attainment & 90 & 0.903 & 104 & 0.960 \\
\hline Health and survival & 66 & 0.974 & 99 & 0.971 \\
\hline Political empowerment & 111 & 0.022 & 119 & 0.087 \\
\hline Rank out of & 115 & & 144 & \\
\hline
\end{tabular}

Finally, according to the Human Development Index, Egypt has been better in 2006 than 2017, which indicates that the wage gap is increasing rather than declining. We are too far away from closing the wage gap and overcoming gender discrimination [15]. As well as that, according to the economic participation, education, health and political empowerment we are doing far worse than before and we dropped in ranking compared to previous years [16]. This is because the percentage of literate men turned out to be more than the women; therefore, employers favor more men to participate in jobs than women. In addition to political participation where far more men join political positions, while very few women co-operate in such occupations, lowering our human development's rank and increasing the gap between both genders. However, Egypt ranks the 115th country out of 189, scoring 0.696 in the Human Development Index (United Nations Development Programme, 2018) (Figure 4). More than half the men are literate compared to women, and therefore are preferable at jobs and get paid higher wages (Figure 5). There is a deficiency of women in political occupations in Egypt, due to gender discrimination (Figure 6).

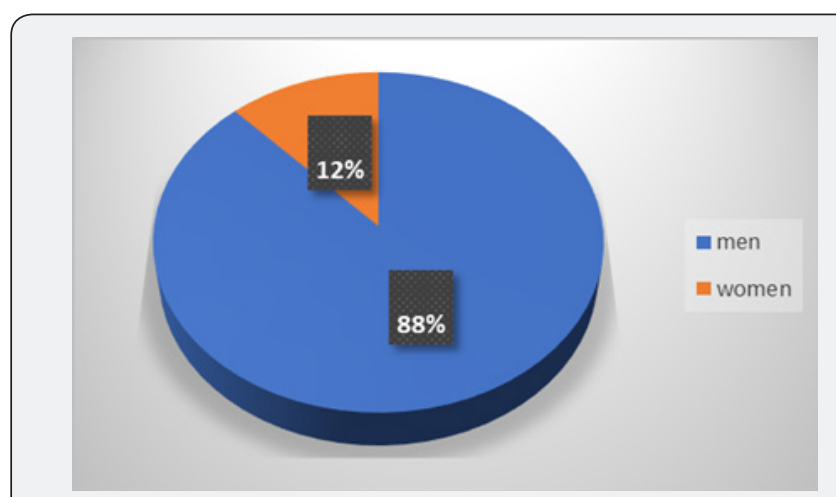

Figure 4: Percentage of Literate Men: Women in 2017, Egypt. Source: The Organization for World Peace, 2017. 


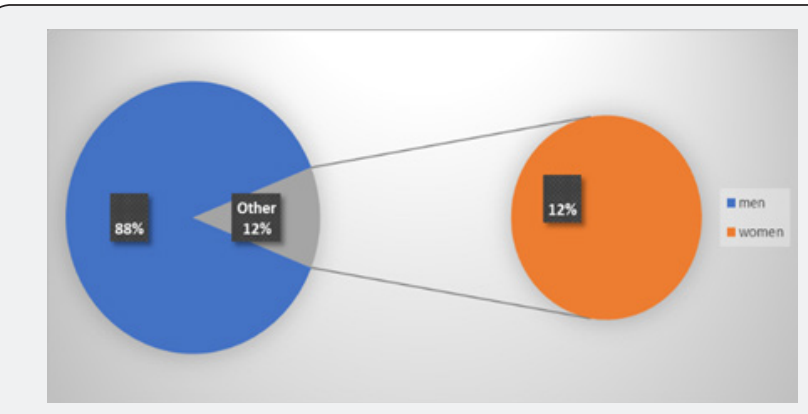

Figure 5: Political Empowerment Men: Women in 2017, Egypt. Source: The Organization for World Peace, 2017.

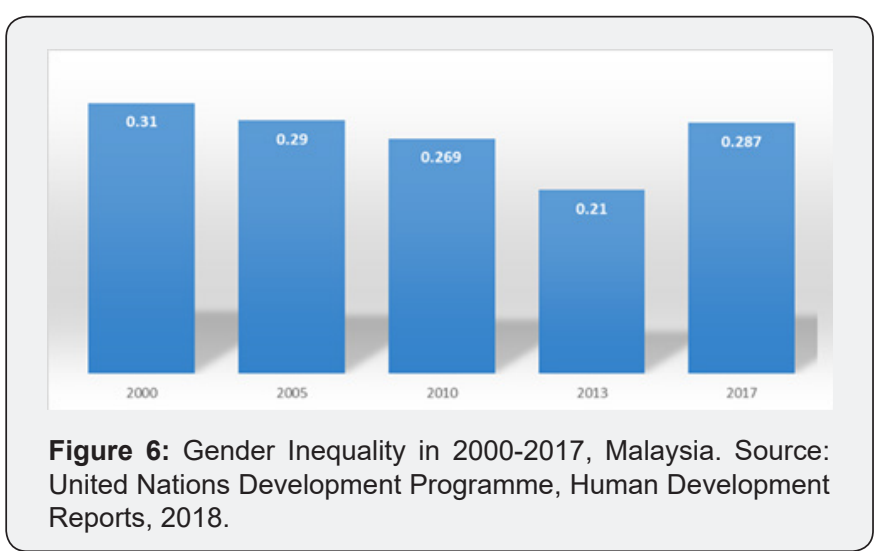

Reports, 2018.

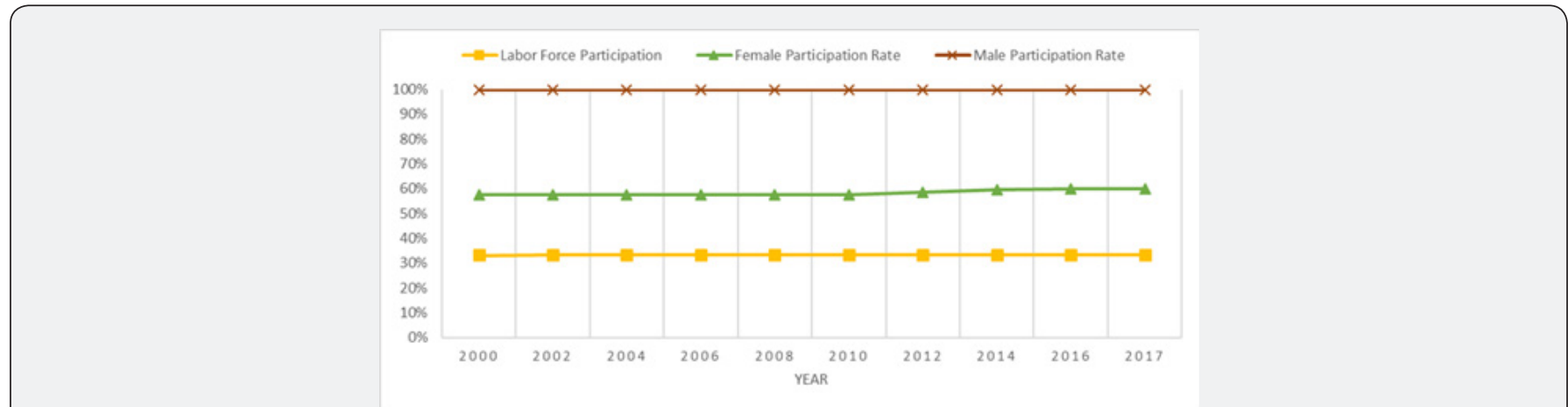

Figure 7: Labor Force Participation Rates in 2000-2017, Malaysia. Source: World Bank, 2017.

Malaysia FLFP and Economic Growth in Economic Growth

Malaysia continues to record small but steady progress on closing its Political Empowerment gender gap and women's share of estimated earned income. Newly available data highlights the fact that the country has fully closed its gender gaps in primary, secondary and tertiary enrolment [17]. Furthermore, Malaysia ranks the 104th out of 144 countries with gender inequality as shown in the (Figure 6) above. We can see an increase in the gender inequality in Malaysia as they do not have a specific law prohibiting workplace discrimination, thus men are more favored than women. Nevertheless, women aging from 25-34 tend to earn more than men until they get married and stay at home or else, as they age, they earn 4\% less than men (New York Times and Department of Statistics Report) (Figure 7).

Note: 15,441,000 people are participating in the labor force (Department of Statistics, Malaysia's Labor Force Participating Survey, 2017). Here as we can see that the males dominate the labor market than women in Malaysia. Their participation rate hits a minimum of $76.14 \%$ in 2010 and a maximum of $78.91 \%$ in 1990 (World Bank, 2017). However, the women participation's rate in the labor market represents a minimum of $43.05 \%$ in 2008 and a maximum of 50.79 in 2017 (World Bank, 207), which still represents large gap between both participations. However, the females' participation shows an increase in the Malaysian market as it reached its maximum in 2017 [18]

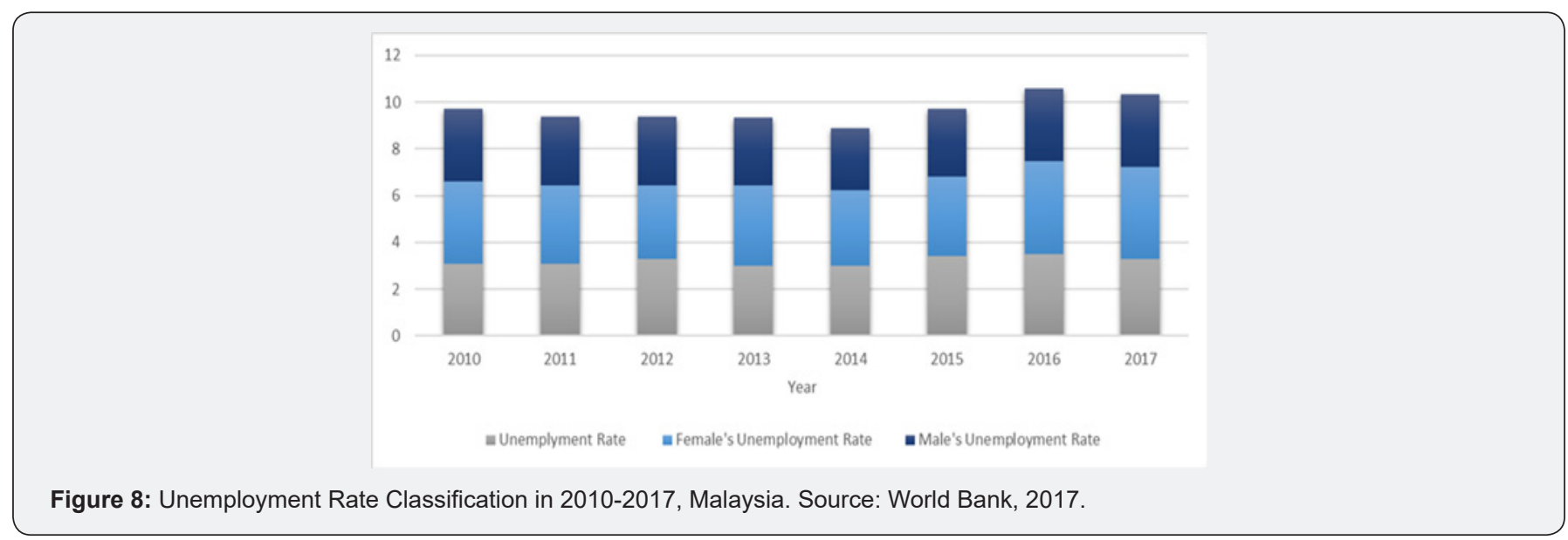


Moreover, the initiatives made by the government and NGO's, facilitating the access to higher education boosted the number of women participating in the labor market. Likewise, providing safety, flexible times and compensation between the work and family's responsibilities aided women to enter the market in 2002 more than before (Ministry of Women, Family and Community Development).

The data shows that the maximum unemployment rate for men reached $2.27 \%$ and a maximum of $3.6 \%$ in 2009 (World Bank, 2017). While, the female's unemployment rate reached a minimum of $2.77 \%$ in 1997 and a peak of $4.39 \%$ in 1991 (World Bank, 2017). This is not a quite big gap; however, the unemployment rate for women started to increase again over time in the Malaysian labor market (Figure 8). Finally, we can see that Malaysia is facing a drop-in rank due to the slowing down in performance economically, educationally and politically. However, there is a development and improvement in the health and survival sector. Furthermore, Malaysia ranks the 57 th out of 189 countries with highest development index od 0.802 (United Nations Development Programme, 2018). Historically, the time that Pakistan was part of the India, due to the Muslim community influence in the 19th century women was forced to wear the "purdah". The purdah was meant to isolate men and women social contact (Table 2).

Table 2: Global Gender Gap Score, Malaysia 2017. Source: World Economic Forum, 2017.

\begin{tabular}{|c|c|c|c|c|}
\hline \multirow{2}{*}{$\begin{array}{c}\text { Global Gender Gap } \\
\text { Score }\end{array}$} & Rank & Score & Rank & Score \\
\cline { 2 - 5 } & 72 & 0.651 & 104 & 0.670 \\
\hline $\begin{array}{c}\text { Economic } \\
\text { participation and } \\
\text { opportunity }\end{array}$ & 68 & 0.592 & 87 & 0.654 \\
\hline $\begin{array}{c}\text { Educational } \\
\text { attainment }\end{array}$ & 63 & 0.985 & 77 & 0.991 \\
\hline Health and survival & 80 & 0.970 & 53 & 0.977 \\
\hline $\begin{array}{c}\text { Political } \\
\text { empowerment }\end{array}$ & 90 & 0.056 & 133 & 0.058 \\
\hline Rank out of & 115 & & 144 & \\
\hline
\end{tabular}

The first empowering women movement was brought about by the reformer Syed Ahmad Khan. He argued that women should have equal education opportunities as men and advocated for female literacy. Muhammad Ali Jinnah, the founder of Pakistan continued this vision. He brought his sister Fatima Jinnah to the political front as a role model. Inspired by Fatima Jinnah many women's organizations and groups established, especially in the urban areas of Pakistan Ejaz (2007). Later, in 1947, after the independence of Pakistan, women were entitled the right to vote under the Pakistan Ordinance [19].

They were reaffirmed and finally voted in the 1956 elections under the interim constitution. In 1956 Pakistan had a reservation of seats for women in the parliament. Nevertheless, Pakistan due to strong cultural norms and religious beliefs still could not completely remove all obstacles and gender inequality persists in all areas Ejaz (2007). The inequalities such as the education and employment gap and limited women's properties compared to men pointing to the fact that despite the efforts the gap persists. The culture of Pakistan is still patriarchal and the percentage of women participating to the paid work is extremely low (24\%) (World Bank, 2013).

\section{FLFP and Economic Growth in Pakistan}

Pakistan was chosen to be examined concerning the influence of an increase in female participation in the labor force on economic growth. Firstly, a general background about the female labor force in Pakistan is needed in order to help in taking a wider look on the situation. Staring from the 19th century, most of the Pakistani women did not engage in paid jobs and the minority of women who were employed in paid jobs mainly consisted of single females with young ages who still do not have family obligations. Consequently, at that time, marriage was considered a factor that prevents women from working; the few married women who had jobs were mostly in the sectors of either textiles or house maids Ehsan (2015).

After then, the structure of female labor force started changing starting from year 1930 when the Pakistani service sector started nourishing following an increase in office work. As a result, the Pakistani labor market demanded more female labor. Moreover, modern technology started to take place at that time in Pakistan, electricity in specific, which was considered satisfactory for females because it helped in reducing the unpaid work that they used to get engaged in and replacing it with paid work Ehsan (2015).

Later in Pakistan, around the 1950s-1970s, women started to get concentrated in educational sectors such as schools and libraries in addition to some minor positions in health sectors such as nurses. At that time, the Pakistani women started to have a position in the society and their participation in the labor force started increasing dramatically. One of the major causes behind the significant growth of FLFP in Pakistan, reaching up to $75 \%$ compared to $40 \%$ growth rate in the 1970 s, is the enhancement of the educational level of Pakistani females in the 1970s-1990s; this reflects how high educational levels for females have a direct effect on the female employment within countries Ehsan (2015).

At the time where the Pakistani female labor force experienced a significant enhancement, especially in the 1990s. This was followed by an improvement in the Pakistani GDP growth; amounting $4.04 \%$ annually, according to statistical data extracted from the World Bank between the period of 1990-2013. Additionally, the highest GDP growth that Pakistan had experienced took place in year 2017 and amounted $5.7 \%$ and the same year coincides with the highest percentage of female participation in the Pakistani labor force Ehsan (2015). The following (Figure 9) will clarify this positive relationship more throughout different consecutive years. 


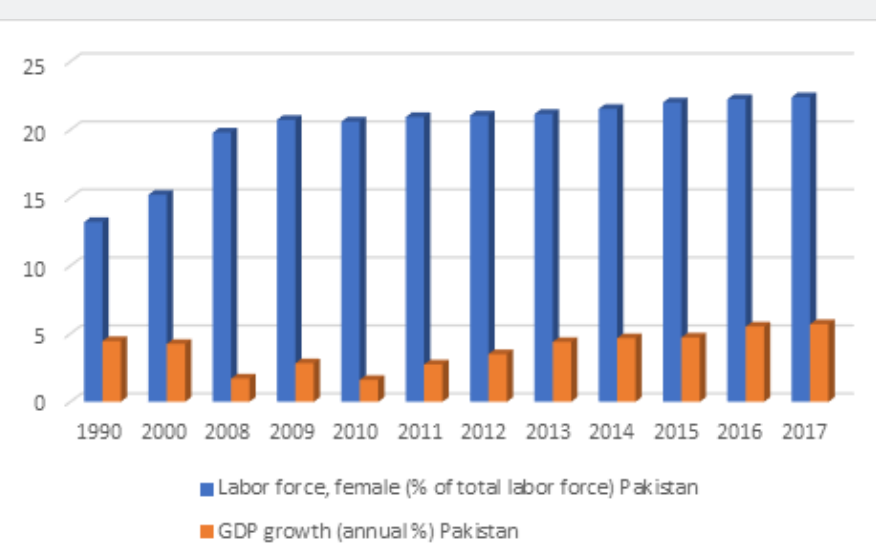

Figure 9: The relationship between Female Labor Force and GDP growth in Pakistan. Source: World Bank (2018) https://data.worldbank. org/indicator/NY.GDP.MKTP.CD?locations=PK.

As (Figure 9) reflects the percentage of Pakistan's female's participation in the labor force in addition to Pakistan's GDP growth starting from the 1990s till year 2017. It can be observed from the above bar chart that there is a positive relationship between the increase in female labor force participation in Pakistan with the country's GDP growth. The shorter bars represent the annual percentage of Pakistan's GDP growth while the taller ones represent the female labor force; the positive relationship between both variables is clear because the increase in female's participation \% of the labor force is followed by an increase in GDP growth and thus, economic growth especially in the year 1990, reaching 13.7\%, and years starting from 2011 until 2017 Ejaz (2007).

Moreover, years from 2000 until 2007, Pakistan have experienced a comparatively improved growth in its economy, average growth rate of 5.1\%, and this also marked a period of an increased participation of females in the Pakistani labor force. Nevertheless, this does not neglect the fact that Pakistani females still suffer from high illiteracy rates during recent years and the gender employment discrimination is still persistent in the Pakistani market. To be more specific, females' illiteracy was concrete more in Pakistan's rural areas. Moreover, Pakistan still lags far behind in comparison to other countries. A factor that needs to be considered over here is that of Islam and religious belief of Muslims in Pakistan that women should stay at home and observe "purdah" and the gender gap in education. Female to male literacy rate was 58.7 Ejaz (2007).

Nonetheless, Pakistan did not really encounter significant economic growth since in the period of the 90's where the service sector took placed and FLFP highly improved. The unemployment level of Pakistan in 2012-2013 stood around 6.54\% on average. Female unemployment was higher than men unemployment level, standing at $9.19 \%$ which could be another factor worth considering why female labor force participation is low Ejaz (2007). It can be observed from (Table 3) that there is a significant Gender Wage Gap that takes place in Pakistan even after the Female participation improved in the Pakistani labor force. Pakistan is close to Egypt in this case, as the culture and social norms are the major factors that arise the concept of gender wage discrimination within the country.

Table 3: GWG in Pakistan (2010-13).

\begin{tabular}{|c|c|c|c|c|c|c|}
\hline \multirow{2}{*}{$\begin{array}{c}\text { Average } \\
\text { Wage in } \\
\text { Rupees }\end{array}$} & \multicolumn{3}{|c|}{ 2010-2011 } & \multicolumn{3}{c|}{ 2012-2013 } \\
\cline { 2 - 7 } & Total & Male & Female & Total & Male & Female \\
\hline Total & 9715 & 10211 & 6422 & 12118 & 12804 & 7869 \\
\hline
\end{tabular}

\section{Case Study: Belgium}

Belgium is one of the top countries, beating gender wage gap compared to other European countries including Sweden, the Norway and Iceland. The recent data provided by the OECD shows that the average monthly wage of a Belgian man is 3.3\% of that of the women. While the average wage gap in the European union is 19.2\% (OECD, 2017).

The wage gap has not always been small. However, it decreased throughout the years. As in 2000 it was $13.6 \%$, decreasing to $11.5 \%$ and $7.5 \%$ in 2005 and 2010, respectively (OECD, 2017). The wage differentials have always been a main concern towards the government; moreover, what made it easier is joining trade unions. In addition, approximately 55\% of the Belgian workers join the trade union and a $96 \%$ of the workers are bargaining agreements they sign. This means that the workers do not individually negotiate their salaries with their boss, but instead it is paid based on an agreed framework based on what they do. Therefore, there is no discrimination against women and hence, the framework makes it impossible for women to get paid less than men.

Likewise, the government did not stop here and took further steps forward. They made a new law which makes it mandatory to take into consideration the gender wage gap when the workers negotiate their wages in the trade union. The law also requires the Federal labor service (SPF) to check and sign off job classifications based on their gender neutrality (Figure 10). Yes, there are more 


\section{Annals of Social Sciences \& Management studies}

men than women in the labor force, however the difference isn't that large as the government is still working on it to make it relatively equal (Figure 11). As we can see the unemployment rate for women is too small, and more likely equal to that of men. Hence, we can say that almost men and women are equal and there is no discrimination.

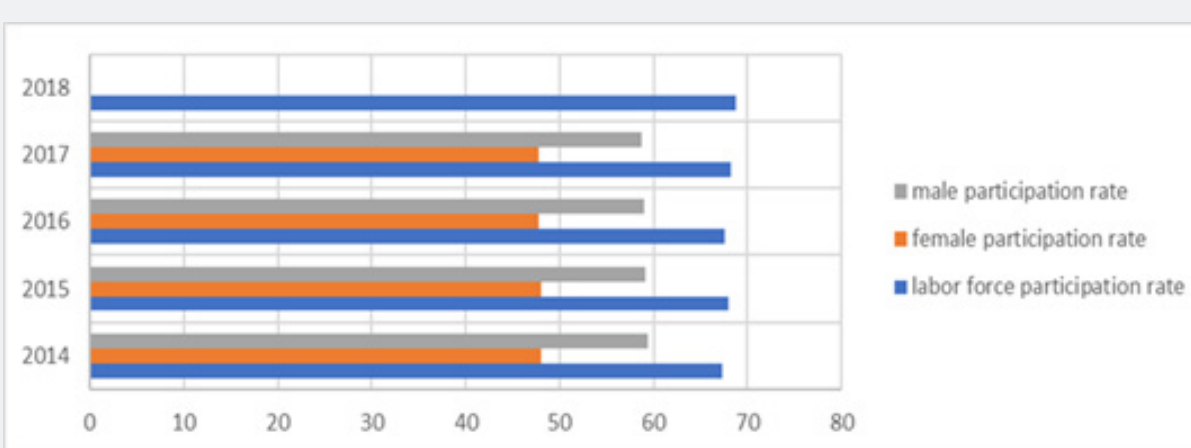

Figure 10: Labor Force Participation rate by gender 2014-2018, Belgium. Source: World Bank, 2018.

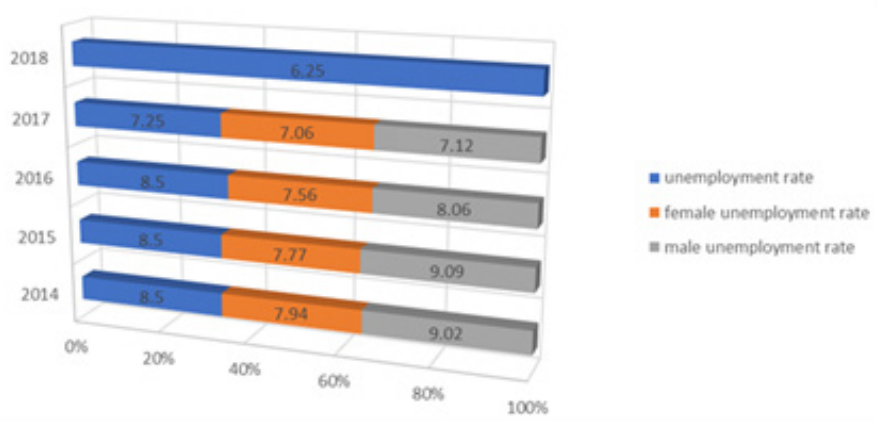

Figure 11: Unemployment Rate by Gender in 2014-2018, Belgium. Source: World Bank, 2018.

Why Belgium is One of the Top Countries with Low Wage Differentials?

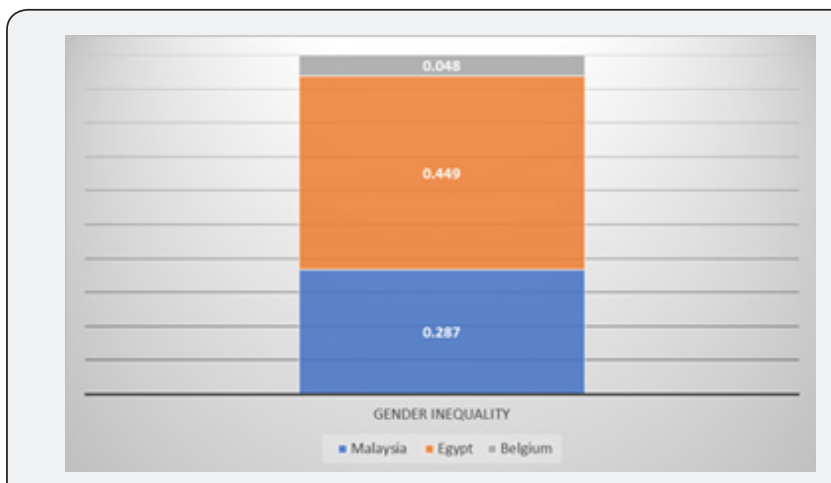

Figure 12: Gender Inequality in Belgium, 2017. Source: United Nations Development Programme, Human Development Reports, 2018.

In 2001, the Belgian Presidency decided to approve which factors affect the wage pay between men and women. In 2006, was the first annual report published showing the wage pay gap in Belgium. It was useful as it provided a measure of every year changes in Belgium and allowed it to know the factors mostly affecting the wage gap. The factors are as follows, gender pay ratios for all employees, part-time work, age, level of education, segregation in the labor market, personal features such as civil status, household composition or nationality and finally, the factors contributing to inequality as defined by the OaxacaBlinder decomposition technique. The reports then highlight the parameters that increase or decrease the wage differentials between men and women. It then distinguishes between the differences that result from discrimination and from how the labor market works. In general, part-time work, age and horizontal professional segregation remain the main factors contributing to the gender pay gap [20]. Finally, the reports help decision and policy makers to take global actions that can close the gender gap as much as possible (Figure 12).

\section{How to Close the Gender Wage Gap?}

First, some of the laws must be reformed in order to protect human rights and eliminate the gap as much as possible. For example, laws such as the Family Medical Leave Act (FMLA), the Pregnancy Discrimination Act (PDA) and Civil Rights Acts Simpson (2013). When they are reformed, they make a huge difference on how women perceive and how they are treated in their workplace. Another additional legislation on taxes that can close the wage gap can be made. Changing the child care tax incentives can influence the number of women who can go back to the work force. Likewise, setting a minimum wage can benefit those who are at the lowest 


\section{Annals of Social Sciences \& Management studies}

spectrum of poverty, and are under poverty line Wong (2013). Thus, adjusting to the new changes in society and demography give a perfect opportunity to change and implement new policies that protect the economies from further gender discrimination.

Organizing awareness campaigns, equality programs and getting government support have a huge pay off on promoting gender equality and higher pay for women. These social programs aid acquiring women with the skills, education and/or benefits to start working again in the labor force. None of the nations are gender neutral, however, we can do the best in order to overcome this discrimination as much as we can. The more programs set in place to promote women, the more women can gain additional equality in earnings.

Another thing is to encourage work-life balance Brummelhuis van der Lippe (2010). Having a child must be no longer a penalty for women. Work-life balance is a theory that encourages career goals and lifestyle choices. Every employee wants to be exceptional in their work and at their homes, having different lifestyles and backgrounds. However, firms must put into considerations those lifestyles and facilitate the needs of the worker. According to Simpson (2013), he highlighted that some of the decisions that support the work-life balance are job sharing and flex time. Moreover, the objective is to allow people return to their work and at the same time be able to meet their household requirements. As a result, the wage gap can be closed further. Treiman and Roos (1983) asserted that the main factor of women getting less pay than men is the lack of training and education.

Women should be stood for that they are more educated and involved in work force than ever, when one is educated the better opportunity, he has for getting a high paid job. As viewed in the above (Figure 13), it shows that the number of women holding a college degree increased from 1970 to 2010 from 11\% to 36\% (US. BLS,2011). Also, according to our countries being studied, the data shows an increase in female's literacy over time as shown in (Figure 14) below.

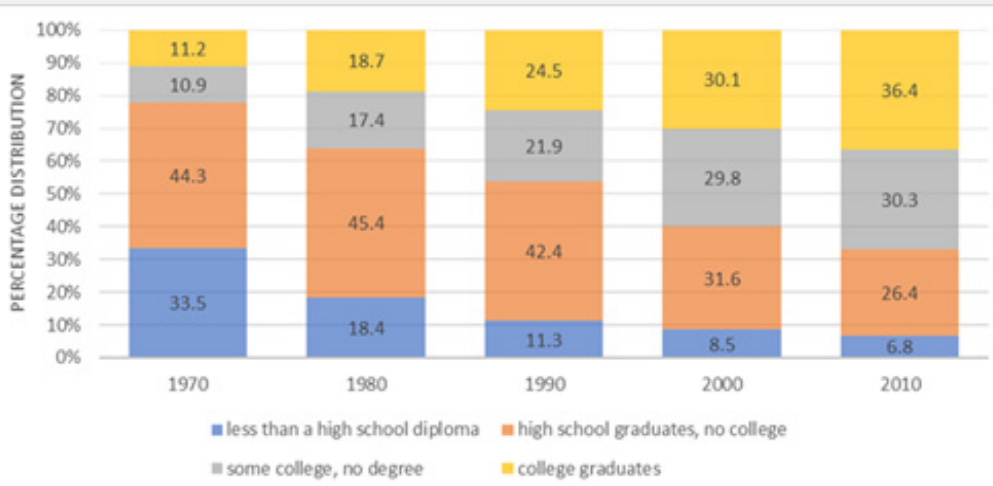

Figure 13: Percent Distribution of Women in the civilian Labor Force, aged 25-64 years, by Educational Attainment, 1970-2010. Source: U.S Bureau of Labor Statistics, 2011.

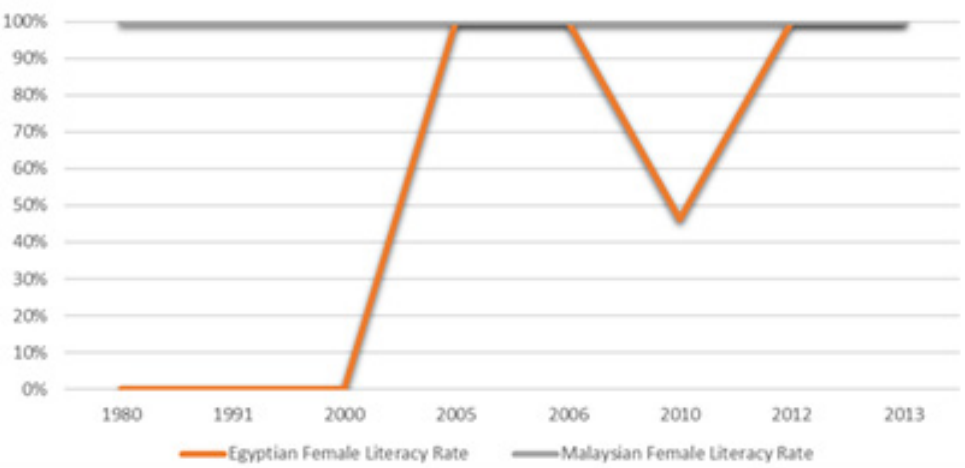

Figure 14: Literacy Rate in 1980-2013, Egypt and Malaysia. Source: World Bank, 2017.

Furthermore, Rose and Hartmann (2004) mentioned that women focusing on male dominated occupations rather than female dominated occupations help closing the gender gap to a high extent. This is known as wage segregation. Treiman and Roos (1983) explained that women prefer specific jobs than men, and these jobs pay less. Ross and Mirowsky (1996) described male dominated to involve hazardous conditions, including temperature, noise, location, more physical labor and additional human capital in education and experience. Economic theory states that the higher the risk, the higher the return. Thus, the more women are indulged in such male-oriented occupation, the higher is their earning. Hence, well-paying jobs are suitable for women if they are willing to go out of their comfort zones. 


\section{Female Participation and Economic Growth}

\section{Impact of Female Participation on Economic Growth}

Economists nowadays agree that gender discrimination has a great influence on economic growth. According to empirical and theoretical studies made, they suggest that female's participation in the labor market undoubtedly promotes growth. The evolution from exogenous to endogenous growth models, rose the recognition of gender specific growth determinants. The models endogenized the advancement in technology by integrating the education with the labor market participation as growth factors.

Knowles et.al. (2002) model suggests that differences in gender's education negatively impact economic growth. Due to the falling marginal returns of human capital, there is larger rates of returns from education to women than to men. Consequently, investing in women's education, acquitting them with the skills and experience, aid promoting economic growth and increasing country's capital stock. How women's education affects the nation? It affects its income in several ways, such as it increases the female's participation in the labor force and accordingly their earnings as well, reducing women's fertility. Galor and Weil (1996) highlighted that a working woman and her participation in the labor market provides households with additional income, which as a result increases the savings amount. This increase in savings will increase the capital stock per worker and therefore, increases output.

Moreover, Klasen and Lamanna (2003) added, that high gender discrimination rate present in the country causes artificial restriction to the "talent pool" of the country's labor force. This is potentially because less qualified men force qualified women out of the market. In conclusion, this artificial low available labor force within the economy makes the country incapable of being internationally competitive. A macroeconomic model made by EU business analysts predicts that an expansion of 5\% in female work constrain cooperation in Southern Mediterranean nations could result in a total $1.3 \%$ expansion in GDP in these nations somewhere in the range of 2015 and 2030 Tsani (2012).

As indicated by the International Monetary Fund, raising the female work constrain cooperation rate to male levels in Egypt would result in a 34\% expansion in GDP. In a World Bank paper on work disparity, increments in ladies' work compel investment were related with enhanced welfare results and productivity on a nation level Tzannotos (1999). Much advancement has been accomplished in the previous couple of decades in narrowing the sexual orientation hole in Malaysia. It tends to be appeared in the improvements in ladies' jobs, both in supreme and relative terms, in the major financial perspectives of the nation's advancement: expanding rates of female work constrain support, gains in profitable exercises of ladies and their reinforced monetary standing and their expanded investment in instruction. Malaysia's noteworthy monetary development has been joined by the more prominent support of ladies in the formal workforce and in a scope of other exercises.
Female labor force participation rate has kept pace with population development and the number of female and male specialists multiplied somewhere in the range of 1970 and 1995, while the labor force participation rate remained generally unaltered after 1980. The labor force rate expanded from the upper thirties for ladies between 1970 also, 1980, and has stayed somewhere in the range of 44 and 46 percent among 1990 and 1995. The quick retention of ladies into the work force has been affected by a few variables. The rapid economic growth was due largely to important growth in the manufacturing and services sectors, where considerable also, relatively bigger increment of female specialists has been enlisted. Among all parts of the economy, the assembling area has recorded the most elevated development rate amid the most recent decade.

The assembling part has made around 0.6 million new employments somewhere in the range of 1990 and 1994. In 1994 the sector provided work to 1.9 million individuals. The development of this sector has driven to the participation of female and their engagement in business, with about 46.4 percent (1990) and 43.4 percent (1995). The financial sector and the government are the main employers of women and it represents around 60 percent of the aggregate work force in these sectors. Agriculture sector not the main employer of ladies anymore and the number of women working in agriculture sector has declined from 40 percent in 1970 to 30 percent in 1995. Ladies specialists have been able to move into generally better paying open doors in different sectors.

\section{Impact of Economic Growth on Female's Participation}

Empirically, the Middle East shows an increase in the female labor force participation till 2012, while East Asia shows a decrease in female participation. On the other hand, the economic growth shows an inverse impact on the female labor force. Whenever the growth increases, the female participation decreases then increases on the long-run. This is shown through the Feminization U' model in (Figure 15) below. In the first stages of country's development, the female participation in the market decreases, then increases at the higher stages of development Boserup (1970).

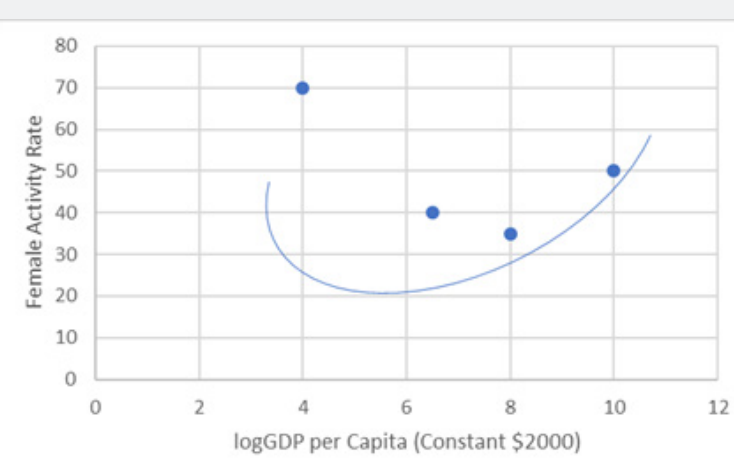

Figure 15: Feminization U' Model. Source: IZA World of Labor 2017. 
At stage 1, the country is a low-income nation and is almost centralized in the agricultural sector. The female participation tends to be too high in these developing countries, as most of the women at that time work on farms in home workshop production. They contribute to family workers or self-employed and at meanwhile, they can still have children. At stage 2, the economic growth starts to show up, the industrialization effect takes its place, leading to some gender discrimination because of the employment differences. Then, the decrease in the agricultural or rural sector and the increase in demand for labor mobility make it difficult for women to compromise between work and children.

As a result, family connections are weakened, and children are now acting as barriers for women's wages. Another thing, due to the structural change and income effect arose from industrialization and urbanization, the demand for high-skilled and technical workers dramatically increased for the new mass dependency on computers and machines. More men started to work than women and they now can maintain the family on their own [21].

Lastly, at stage 3, the female participation starts to increase all over again. The exclusion of women from wage activities results in a tight labor market, and the demand for women starts to increase. Competitive countries want to optimize their talent pool and acquire women with training and education. Women's job opportunities increase, and hence increases the opportunity cost of staying at home. Therefore, female labor market participation increases in the medium and long run, due to women's time lagged adaption to new qualification and requirement profiles of the labor market and a dominating substitution effect (Figure 15).

\section{Conclusion}

In this paper, we have seen the different driving forces of gender wage disparities. Some of the main obstacles that face women are education, childcare, traditional reputation and administrative jobs that limit their job opportunities than men. Moreover, we examined the different driving forces that both countries face, leading to gender discrimination in wage pay. However, each country differs than the other in such disparities. According to our research, we have known for instance that in Egypt, the private and public sectors have major contribution to paying different wages.

Private sectors dramatically neglect women's rights in the labor market such as, sick leave, working hours and sexual harassment, etc. while, in the public sector, they are more responsible towards women and pay higher wages for them than in private. As well as in the informal sector, they highly discriminate against men and women in wage pay and thus, women get paid so much lower than men even in the compensations. Another driving force is marriage. The female's participation rate decreases when they get married, and men are left with greater job opportunities. On the other hand, in Malaysia the most important factors are the human capital, job characteristics and education.
Despite the increase in Malaysian women's literacy rate, their productivity level is said to be lower than men and therefore are getting paid by gender for profit maximization. In addition, the fertility rate has a major impact as well, as the greater number of children the woman has, the more she's disrupted from seeking good job opportunities. Men in Egypt dominate more than half the labor market and are paid $29 \%$ higher than women. However, the gender inequality rate has decreased due to the constitution made in 2014 protecting women and the awareness campaigns made. Adversely, Malaysian women get paid only $9 \%$ lower than men and they earn $71 \%$ of their wages. While, gender inequality increases due to the lack of laws protecting women.

In order to overcome wage gap problem, we must develop laws such as pregnancy discrimination act and family medical care leave act. Also, raising awareness for gender equality and programs promoting life-balance techniques can have a major positive effect on women's lives and jobs. As well as, setting minimum wage rate to protect those on the verge of facing poverty. Finally, we have shed light on the main factors causing wage disparities between men and women up until now in the 21st century and knew how to close the gap as much as possible. Also, we proved the positive impact women's participation have on economic growth on the long run.

\section{References}

1. Rajbhandari, MMS, Rajbhandari, S (2015) Leadership maintenance: Filling the gap for leadership competences. Educational Research and Reviews 10(21): 2777-2788.

2. Rajbhandari, MMS (2015) Critical Perspective on Situational Leadership Theory. Leadership Readiness for Flexibility and Mobility The $4^{\text {th }}$ Dimensions on Situational Leadership Styles in Educational Settings. Europe.

3. Rajbhandari, MMS (2016) Why do educational leaders need maintenance? International Journal of Educational sciences 12(1): 1-6.

4. Darmawan (2010) Bullying in school: A study of Forms and Motives of Aggression in Two Secondary Schools in the city of Palu, Indonesia. Master's Thesis. University of Troms $\varnothing$ Norway. Indonesia.

5. VanDamme, E (2012) Identification and prevention of bullying in schools. Master's Thesis. Northern Michigan University. USA.

6. Eriksen, T, Nielsen, H, Simonsen (2012) The effects of bullying in elementary school. Economics Working Papers. Europe.

7. Quine, L (1999) Workplace bullying in NHS community trust: staff questionnaire Survey. BMJ 318: 228-232.

8. Rajbhandari, MMS (2011) Driving Leadership Style in Leading to Enhance Participation and Involvement in School. Europe.

9. Rajbhandari, MMS (2015) How Does Maintenance of Psycho-SocioPhysio Parameters Enrich Educational Leaders? Journal of Educational Thought/Revue de la Pensée Educative 48(3): 239-254.

10. Rajbhandari, MMS (2018) Theoractive Learning towards Academic Endeavour. Journal of Interdisciplinary Sciences 2(1): 1-7.

11. Rajbhandari, MMS (2017) Leadership Elasticity Enhancing StyleFlex for Leadership Equilibrium. International Journal of PsychoEducational Sciences 6(2): 76-88.

12. Michael JL Sullivan, Michael Conway (1989) Negative Affect Leads to Low-Effort Cognition: Attributional Processing for Observed Social Behavior. Social Cognition, 7(4): 315-337. 


\section{Annals of Social Sciences \& Management studies}

13. Mathews, G, Deary, IJ (1998) Personality Traits, Cambridge University Press, Cambridge, England.

14. Yazdanpanah M, Hadji Hosseinlou M (2017) The role of personality traits through habit and intention on determining future preferences of public transport use. Behavioural Sciences (Basel) 7: 1.

15. Weston, SJ, Hill PL, Jackson, JJ (2014) Personality traits predict the onset of disease. Social Psychological and Personality Science 72(6): 913-921.

16. Borghans Lex, Duckworth Angela L, Heckman James J, Weel Bas ter (2008) The Economics and Psychology of Personality and Motivation Journal of Human Resources, Discussion, P. 3333.

17. Khondker, HH, Schuerkens, U (2014) Social transformation, development and globalization. Sociopedia.isa. UAE.

18. Webster C (2008) The Sociology of Transformation and the Transformation of Sociology in Southern Africa. Social Dynamics 24(2): 117-129.

19. Munck, R (1996) For a sociology of transformation. Transformation 29 41-52.

20. Kabat-Zinn, J (2015) Mindfulness. Mindfulness 6(6): 1481-1483.

21. Davis DM, Hayes JA (2011) What are the benefits of mindfulness? A practice review of psychotherapy-related research. Psychotherapy 48: 198-208.

22. Thompson, C (2010) Everyday mindfulness. A guide to using mindfulness to improve your well-being and reduce stress and anxiety in your life. Europe.

23. Bandura A (1977) Social learning theory. Englewood Cliffs, NJ: Prentice-Hall, P. 247.

24. Oberlander, DM (2013) Negative Leadership. Master's Thesis. United States Army War College, USA.

25. Sergiovanni, TJ (1995) The politics of virtue: A new compact for leadership in schools. School Community Journal 5(2): 13-22.
26. McSparron, JI, Vanka, Smith, CC (2019) Cognitive learning theory for clinical teaching. Clinical Teacher's 15: 1-5

27. Yilmaz, K (2011) The cognitive perspective on learning: its theoretical underpinnings and implications for classroom practices. The Clearing House: A Journal of Educational Strategies, Issues and Ideas 84(5): 204-212.

28. Chaffin, A, Harlow, S (2005) Cognitive learning applied to older adult learners and technology. Educational Gerontology 31(4): 301-329.

29. Grider G (1993) Foundations of cognitive theory: A concise review. Los Angeles, CA, USA: ERIC Clearinghouse for Community Colleges, USA.

30. Smith, M, Berge, Z (2009) Social learning theory in Second Life. The MERLOT Journal of Online Learning and Teaching 5(2): 439-445.

31. Grusec,JE (1994) Social learning theory and developmental psychology: The legacies of Robert R Sears and Albert Bandura. In RD Parke, PA Ornstein, JJ Rieser, C Zahn Waxler (Eds.), A century of developmental psychology (pp. 473-497). Washington, DC: American Psychological $\neg$ Association. UAS.

32. Wong, SW (2012) Operant learning theory. In Thyer, BA, Dulmus, CN, Sowers, KM (Eds.). Human behavior in the social environment: Theories for social work practice, 83-123. Wiley, New York.

33. Skinner, BF (1966) Operant behavior. In: Honig WK, editor. Operant Behavior: Areas of Research and Application. Appleton-Century-Crofts; New York, p. 12-32.

34. Pavlov, IP (1927) Conditioned Reflexes: An investigation of the physiological activity of the cerebral cortex. Ann Neurosci 17(3): 136141.

35. Rajbhandari, MMS (2006) Dominant leadership style in schools. Europe.

36. Hoel, H, Rayner, Cooper, CL (1999) Workplace bullying. In CL Cooper, IT Robertson (Eds.), International review of industrial and organizational psychology. New York, NY, US: John Wiley \& Sons Ltd 14: 195-230.

\begin{tabular}{l} 
Your next submission with Juniper Publishers \\
will reach you the below assets \\
- Quality Editorial service \\
- Swift Peer Review \\
- Reprints availability \\
- E-prints Service \\
- Manuscript Podcast for convenient understanding \\
- Global attainment for your research \\
- Manuscript accessibility in different formats \\
( Pdf, E-pub, Full Text, Audio) \\
- Unceasing customer service \\
Track the below URL for one-step submission \\
https://juniperpublishers.com/online-submission.php \\
\hline
\end{tabular}

